\title{
SUNT LACRIMAE RERUM
}

Un anciano desnudo, de pie en un charco, susurra endechas, se dobla lentamente en la feroz intemperie, dibuja un agudo lamento en la entraña agridulce de la brisa matinal.

Habla con la voz de un colibrí; tiene un gesto de águila derrotada.

Pasa el viento invisible.

Pasan objetos sin nombre.

Pasa un perro de ojos heroicos.

En la boca del tiempo

el anciano comienza

a tiritar.

Da la hora en el verdor de las 9 de la mañana.

Las cosas cierran los ojos, empapadas. 